\title{
Allergic Fungal Rhinosinusitis in Children: Short Communication
}

\author{
Luis Seguias* \\ Pediatric Coordination of Care Program Director, University of Florida, USA
}

Submission: July 04, 2019; Published: July 16, 2019

*Corresponding author: Luis Seguias, Pediatric Coordination of Care Program Director, University of Florida, Gainesville, Florida, USA

\section{Introduction}

In 1976, Allergic Fungal Rhinosinusitis (AFRS) was first reported by Saferstein [1] as a unique clinical entity in patients with nasal obstruction caused by Allergic Bronchopulmonary Aspergillosis. AFRS is an important subtype of chronic sinusitis that represents $5 \%$ to $10 \%$ of adults that requires surgical treatment [2]. The prevalence in pediatric and adolescent age population has not been well established. Geographically, AFS is more prevalent in the Southeastern United States and in other humid climates around the world [3]. The pathogenesis of AFRS is not yet fully understood and is a subject of controversy. Manning and Holman proposed a pathogenic immunological mechanism initiated by antigenic stimulus, followed by hypersensitivity reaction and a resultant self-perpetuating cycle of inflammation, obstruction, and antigenic exposure [4]. Also, there is evidence that fungus contributes to pathogenesis in AFRS by promoting a Th2 response and also that fungal components themselves are pathogenic [5].

Clinical manifestations can include rhinorrhea, nasal obstruction, headaches, itchy eyes and anosmia. Nasal polyposis is a very common finding $\sim 90 \%$ cases [6]. In approximately $50 \%$ of children with AFRS accumulation of mucin can experience sinus expansion resulting on facial dysmorphia and proptosis [7]. It is not rare to have radiological evidence of orbital erosion in severe cases [8]. Demographically, boys are more commonly affected than girls and African American children often present earlier and with more severe disease [9]. Patients with it commonly are immunocompetent, and up to $50 \%$ of patients have comorbid allergic rhinitis or asthma [4]. Bent and Kuhn Diagnostic Criteria[10] is the most accepted by the experts and include characteristic CT imaging findings, evidence of eosinophilic mucus with positive fungal stain, and proven type I hypersensitivity by skin testing or serology (Table 1). Patients must meet all the major criteria for diagnosis, while the minor criteria serve to support the diagnosis and describe individual patients but are not used to make a diagnosis. The histopathologic findings in AFS are critical to the diagnosis. Most of the surgical specimens demonstrated allergic mucin rich on eosinophils along with the characteristic Charcot-Leyden crystals. Fungi can be isolated from the mucin but does not invade the nasal and sinusal mucosa. Fungal cultures should be interpreted with caution. AFRS often is associated with dematiaceous fungi, being the most common isolation Aspergillus species [11].

Table 1: Proven Type I Hypersensitivity by Skin Testing or Serology.

\begin{tabular}{|c|c|}
\hline Major & Minor \\
\hline Type I hypersensitivity & Asthma \\
\hline Nasal polyposis & Unilateral disease \\
\hline Characteristic CT scan findings & Bone erosion \\
\hline Eosinophilic mucin without invasion & Fungal cultures \\
\hline Positive fungal stain & Charcot-Leyden crystals \\
\hline Serum eosinophilia & \\
\hline
\end{tabular}

Treatment of AFRS typically includes endoscopic sinus surgery to enlarge the sinus ostia and remove eosinophilic mucin. Saline irrigations are routinely used postoperatively to prevent mucin accumulation. Recent data supports the use of a short course of postoperative oral corticosteroids in the management of postoperative AFRS [12]. Leukotriene modifiers and anti-inflammatory macrolide antibiotics are often employed to try to reduce steroid requirements, but it is unknown if these improve outcomes or reduce the need for revision surgery. A recent meta-analysis reported no statistically significant benefit of systemic or topical antifungal therapy over placebo in the treatment of chronic sinusitis [13]. Complications from allergic fungal sinusitis are exceedingly rare but bacterial superinfection can lead to infectious sinusitis and less commonly to orbital abscess and cavernous sinus thrombosis. In summary, although AFRS is uncommon in the pediatric population a good clinician should be able to distinguish it from bacterial sinusitis, because management of the two differs considerably, and morbidity can be significant if treatment of AFRS is delayed.

\section{References}

1. Safirstein BH (1976) Allergic Bronchopulmonary Aspergillosis with Obstruction of the Upper Respiratory Tract. Chest Journal 70(6): 789790. 
2. Schubert MS, Goetz DW (1998) Evaluation and treatment of allergic fungal sinusitis. I. Demographics and diagnosis. J Allergy Clin Immunol 102(3): 387-394.

3. Ferguson BJ, Barnes L, Bernstein JM (2000) Geographic variation in allergic fungal rhinosinusitis. Otolaryngol Clin North Am 33(2): 441449

4. Manning SC, Holman M (1998) Further evidence for allergic pathophysiology in allergic fungal sinusitis. Laryngoscope 108(10): 14851496.

5. Tyler, Matthew A. and Luonga Amber U (2018) Current understanding of allergic fungal rhinosinusitis. World J Otorhinolaryngol Head Neck Surg 4(3): 179-185

6. Campbell JM, Graham M, Gray HC, Bower C, Blaiss MS, et al. (2006) Allergic fungal sinusitis in children. Ann Allergy Asthma Immunol 96(2): 286-290.

7. McClay JE, Marple B, Kapadia L, Biavati MJ, Nussenbaum B, et al. (2002) Clinical presentation of allergic fungal sinusitis in children. Laryngoscope 112(3): 565-569.

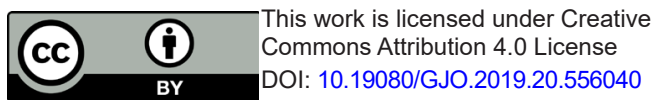

8. Bozeman S, Richard de Shazo, Stringer S, Wright L (2011) Complications of allergic fungal sinusitis. Am J Med 124(4): 359-368.

9. Wise SK, Venkatraman G, Wise JC, DelGaudio JM (2004) Ethnic and gender differences in bone erosion in allergic fungal sinusitis. Am J Rhinol 18(6): 397-404.

10. Glass Daniel , Amedee Ronald G (2011) Allergic Fungal Rhinosinusitis: A Review. Ochsner J 11(3): 271-275.

11. Katzenstein AL, Sale SR, Greenberger PA (1983) Allergic Aspergillus sinusitis: a newly recognized form of sinusitis. J Allergy Clin Immunol 72(1): 89-93.

12. Gan EC, Thamboo A, Rudmik L, Hwang PH, Ferguson BJ, et al. (2014) Medical management of allergic fungal rhinosinusitis following endoscopic sinus surgery: an evidence-based review and recommendations. Int Forum Allergy Rhinol 4(9): 702-715.

13. Sacks PL IV, Harvey RJ, Rimmer J, Gallagher RM, Sacks R (2012) Antifungal therapy in the treatment of chronic rhinosinusitis: a meta-analysis. Am J Rhinol Allergy 26(2): 141-147.

\begin{tabular}{l} 
Your next submission with Juniper Publishers \\
will reach you the below assets \\
- Quality Editorial service \\
- Swift Peer Review \\
- Reprints availability \\
- E-prints Service \\
- Manuscript Podcast for convenient understanding \\
- Global attainment for your research \\
- Manuscript accessibility in different formats \\
( Pdf, E-pub, Full Text, Audio) \\
- Unceasing customer service \\
Track the below URL for one-step submission \\
https://juniperpublishers.com/online-submission.php \\
\hline
\end{tabular}

